\title{
REVIEW
}

\section{BIOLOGICAL CONTROL AND BIOACTIVE MICROBIAL METABOLITES: A COFFEE QUALITY PERSPECTIVE}

\author{
Controle biológico e metabólitos microbianos bioativos: uma perspectiva da qualidade do café
}

\author{
Sara Maria Chalfoun ${ }^{1}$
}

\begin{abstract}
The improvement of techniques of biological control and the use of metabolites produced by microorganisms to obtain products that can be applied in various fields, is getting stronger in face of the undeniable advantages in relation to the models currently in adopted. This review, besides general considerations about the principles and the application of measures of biological control and usage of metabolites produced by microorganisms as sustainable alternatives for the agrochemical segment, among others, reports the experience lived by the author and the institutions to which she is associated, concerning identification, characterization and development of a biological fungicide resulting from the encapsulation of the fungus Cladosporium cladosporioides (Fres.) de Vries, after proving its bioprotecting action on the quality of the coffee. The possibility of using microorganisms as a source of metabolites obtained from biological extracts, with applications in various fields, is also presented and discussed.
\end{abstract}

Index terms: Biological fungicides, fungus metabolites, coffee, Cladosporium cladosporioides (Fres.) de Vries.

\section{RESUMO}

O aprimoramento das técnicas de controle biológico e o aproveitamento de metabólitos produzidos por microrganismos para obtenção de produtos aplicáveis em várias áreas do conhecimento humano, vem se fortalecendo diante de inegáveis vantagens em relação aos modelos hoje adotados. A presente revisão, além de considerações gerais sobre princípios e aplicações de medidas de controle biológico e de aproveitamento de metabólitos produzidos por microrganismos como alternativas de sustentabilidade para o segmento de agroquímicos entre outros, relata a experiência vivenciada pela autora e instituições às quais encontra-se associada com relação à identificação, caracterização e desenvolvimento de um fungicida biológico resultante do encapsulamento do fungo Cladosporium cladosporioides (Fres.) de Vries, após a comprovação de sua ação bioprotetora sobre a qualidade do café. A possibilidade da utilização de microrganismos como fonte de metabólitos obtidos de extratos biológicos, com aplicações em vários setores do conhecimento, também é apresentada e discutida.

Termos para indexação: Fungicidas biológicos, metabólitos fúngicos, café, Cladosporium cladosporioides (Fres.) de Vries.

(Received in june 28, 2010 and approved in September 30, 2010)

\section{Fungus associated to coffee grains and fruits}

Various fungi are found associated to coffee grains and fruits throughout the productive cycle and may, under specific conditions, cause loss of quality, producing foul odors and unpleasant flavor. They can sometimes produce toxic metabolites (micotoxins), compromising the safety of the final product.

The first reports of the influence of fungi on the quality of coffee date from 1936, when Krug (1940a) noticed, using a pocket magnifier, the presence of a reddish mycelial fungus initially identified as belonging to the Fusarium genus. Thenceforth he began a series of works about the origin of hard coffees. He initially studied the influence of coffee picked from the ground on the quality of the beverage. He found a relation between bad quality beverage and the presence of grains picked from the ground, as well as an increase of the reddish mycelial fungus identified as Fusarium concolor. Krug (1940b) studied the microbiota of coffee grains in the cherry, grounded-dry, and dry-on-ground, and found a percentage of $0 \%, 13 \%$ and $20 \%$ bacteria, and $0 \%, 2 \%$, and $13 \%$ fungi, respectively. Regarding the difference in coffee quality between regions, Krug (1940c) made a survey and found a superior percentage of Fusarium concolor in lower-quality beverages.

Although studies about the microbiota of coffee grains and fruits and their influence on the quality of the beverage are old, more thorough studies about the population of microorganisms have only begun to appear from 1990 onwards, seeking to shed light on the related

${ }^{1}$ Agricultural and Livestock Minas Gerais State Research Institution - EPAMIG - P.O. Box 176 - 37200-000 - Lavras, MG - Brazil - chalfoun@epamig.ufla.br 
factors thereof. Subsequently, countless genera and species of filamentous fungi were identified that are associated to fermentation processes occurring during the phases of development of the fruits until postharvest, related to the production of lower-quality beverage (Amorim \& Mello, 1989; Silva et al., 2000; Favarin et al., 2004; Schimidt et al., 2010), as well as the more common genera Aspergillus e Penicillium, associated with micotoxins (Pitt et al., 2000; Taniwaki et al., 2003; Chalfoun \& Parizzi, 2008), which occur in cereals, grains and seeds at levels that make food improper for consumption (Figure 1).
In some regions or in certain years coffee quality was inferior due to environmental conditions, mainly related to temperatures and relative air humidity favoring the development of microorganisms (bacteria, fungi, yeast) that had a negative impact on the quality of the coffee. Throughout the research developed to verify the role of microorganisms in the quality, it was observed that, contrary to the other ones, the genus Cladosporium was associated to good quality beverages (Chalfoun et al., 2007). This relation, confirmed by other researches and later observations, raised interest for its usage as an antagonist agent against fungi deleterious to quality of the coffee(Figure 2).

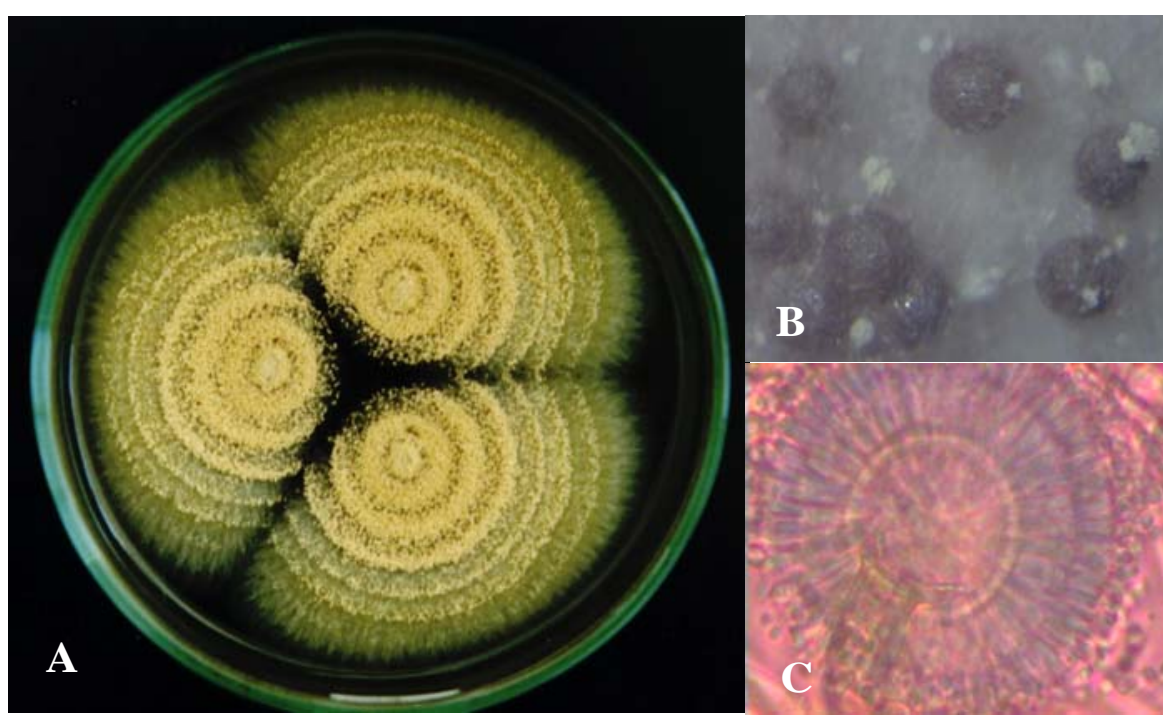

Figure 1 -Aspergillus ochaceus: A) morphological aspects of the colony; B) Golden-yellow and cream-colored scleroria; C) conicial biseriate heads. Source: Chalfoun \& Batista, 2003.

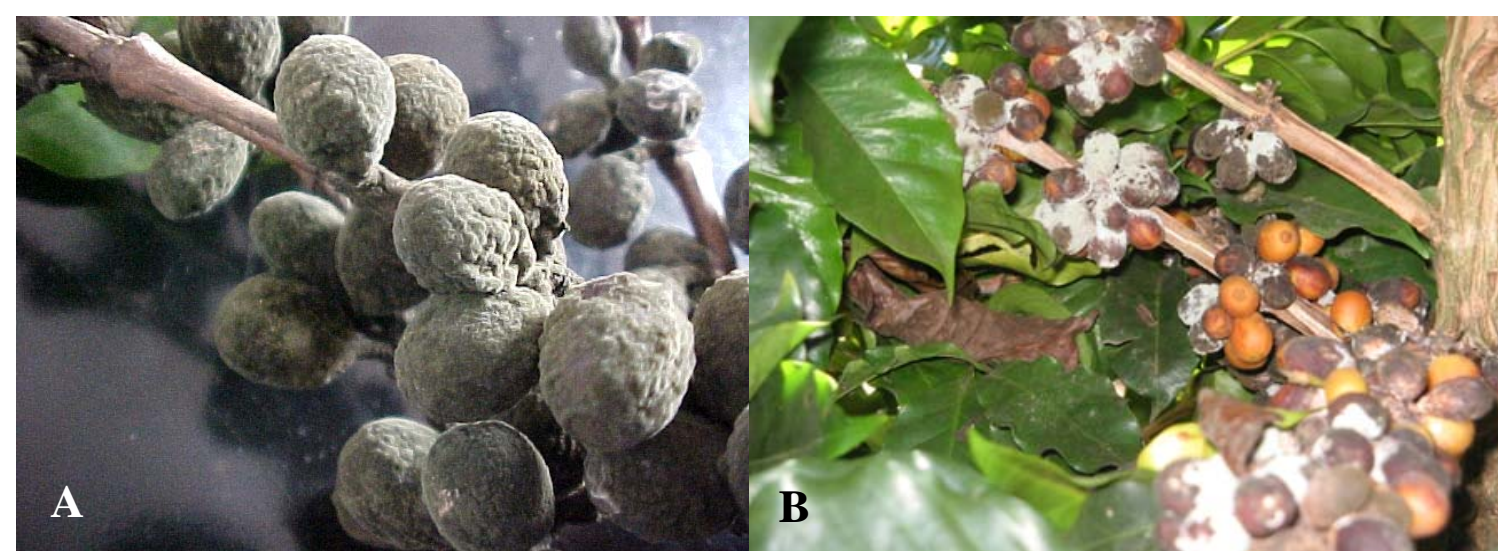

Figure 2 - Coffee tree branches: A) coffee fruits colonized by the fungus Cladosporium cladosporioides; B) fruits colonized by fungi harmful to coffee quality.

Ciênc. agrotec., Lavras, v. 34, n. 5, p. 1071-1085, set./out., 2010 
The first report of Cladosporium in coffee grains was made by Bitancourt (1957), who found out that Cladosporium had different behavior from other fungi; it was not found on the ground, but in the fields up until the stage of dry on tree. In the region of superior relative humidity, there was less incidence of Cladosporium and the quality of the beverage was worse, the opposite occurring in dry weather regions.

The association between better quality and presence of Cladosporium demanded that it be characterized in order to make it possible to introduce it as a bioprotection agent. After isolation and purification of the fungus directly collected from the colonized coffee fruits, following the methods proposed by Samson et al. (2000), the fungus was found to belong to the species Cladosporium cladosporioides (Fres.) de Vries. The main distinctive characteristics that allowed the identification of the species(Figure 3), were the prominent conidial scars, conidiophores without nodules, conidia without septa or only a common septum, and ellipsoidal or lemon-shaped format (Chalfoun et al., 2007).

\section{The genus Cladosporium}

The genus was described for the first time by Link in 1815. It comprises approximately 500 species, 15 of which are of common occurrence. Cladosporium is a mitosporic ascomycotic fungus, subphylum Pezizomycota, class Dothideomycetes and family Mycosphaerellaceae. The fungus presents effuse or occasionally punctiform colonies, frequently of olive-green, but also grey, light yellow, brown, black or greyish color, of velve-like or flaky touch. The mycelium can be immersed or superficial; stroma sometimes without hyphopode or arrows (Kirk et al., 2001). The conidiogenic cell is polyblastic, normally integral, terminal and interspersed, often discrete, sympodial, more or less cylindrical-scarred, with normally prominent marks. The conidia are often in chains or solitary in the big conidia species. Ramified chains form simple, big cylindrical, dolliform, ellipsoid, fusiform, oval, spheroid or subspheroid acropetal cronidia, often with a protuberant basal or nearbase scar, of brown-olive-to-black color, warty or thorny with 0 to 3 or more septa (Ellis, 1971). The conidia of this genus are well adapted to air dispersion, small, pigmented and very resistant to sunlight. Their form is akin to yeast cells, but they present thick, olive-green, rough walls (Pitt \& Hocking, 1997).

\section{Characterization oh the fungus Cladosporium cladosporioides as a safe microorganism}

Once taxonomically identified, the fungus Cladosporium cladosporioides (Fres.) de Vries ,researchers started looking for the possibility of establishing its Qualified Presumption of Safety (QPS) status, presumption being defined as "as assumption based in reasonable evidence”. The system was recently proposed by the EU regulatory authorities and is similar in concept and purpose to the GRAS (Generally Recognized as Safe) definition used in the USA, which could be applied to microorganisms and eventually their products(Figure 4). It is evident that such scheme should not compromise safety but should ideally improve, extend, clarify and make more consistent the approval procedures for micro-

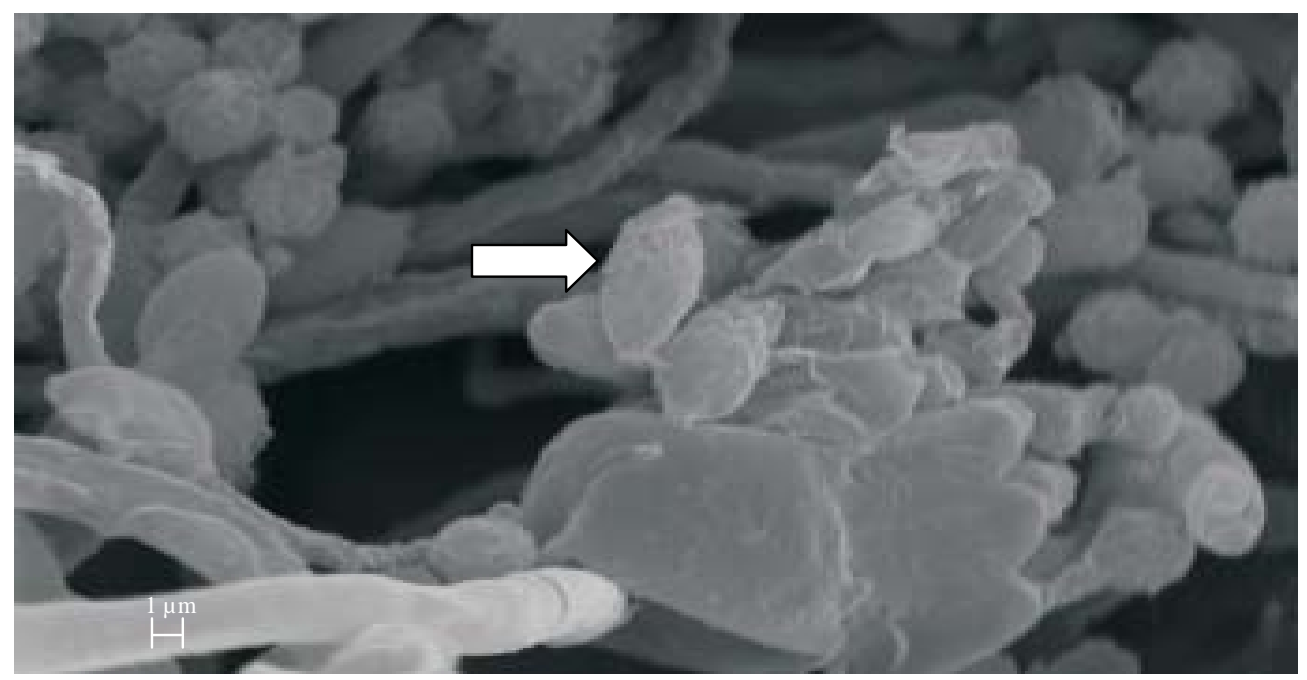

Figure 3 - Electromicrography of fungus Cladosporium cladosporioides showing characteristic conidium. 
organisms and, where possible, allow a more generic approach more consistent the approval procedures for microorganisms and, where possible, allow a more generic approach (Zeigler \& Perkins, 2008).

Whatever the use and identify of the organism(s), there are a series of general conditions that would have to be met before QPS status could be established. The start point is taxonomic identification, i.e., that the fungus be identified at the genus and species level. The second test is familiarity and, in particular, the degree of familiarity. In this context, familiarity is taken to include practical experience of use of the organism(s) including its history of use for particular purposes and any literature on the biology of the taxonomic unit. Judgment as to whether the organism (s) can be considered familiar should be based on a weight-ofevidence approach. This must be sufficient to provide adequate assurance that any potential to produce adverse effects in humans, livestock or the wider environment is understood and predictable.

The consulted literature shows that species of the genus Cladosporium are capable of producing metabolic substances that can be of interest to man. For instance, according to Gallo et al. (2004), a marine species of Cladosporium sp. is capable of producing a powerful antibiotic inhibiting Bacillus subtilis and Eschericha coli, also presenting some components that reduce the growth of Candida albicans. Species of the Cladosporium genus are also used in the biological control of insects plant-hosting insects like aphids, for insects have been developing resistance to chemical insecticides. Cladosporium herbarum is effective in the control of white flies that attack crops (Abdel-Baky \& Abdel-Salam, 2001). Various microorganisms are able to promote bioremediation of heavy metals. Works have used Cladosporium cladosporioides to absorb cadmium, copper, chromium, gold, nickel, silver and zinc (Modak, 1995; Pethkar \& Paknikar, 1998, 2001, 2003). In 1998 a new enzyme, $\mathrm{N}$ - alkulglycine oxidase, synthesized by Cladosporium sp., was found. This enzyme is used in the production of pharmaceutics indicated to the treatment of nervous system degenerative diseases such as Parkinson's Disease, because it protects neurons (Gomi \& Horiuchi, 1998). Besides, there is no evidence that the fungus produces micotoxins. On the contrary, Cladosporium cladosporioides can degradate ochratoxin A produced by Aspergillus ochraceus (Abrunhosa et al., 2002; Pereira, 2008). Its pathogenicity is limited to other cultures and the mechanism underlying these pathologies is understood and testable.
The final question relates to end use; in essence, it has different possible outcomes. Cladosporium cladosporioides would fit in the case in which the organism is a componente of a final product, but not proposed to enter the food chain, though that might happen. The consideration about the application of the fungus as an agent to protect the quality of the coffee is based initially on its action on the coffee fruits still on the plant and/or in the drying of the grains, when the formation of off-flavors can occur. The dynamics of Cladosporium cladosporioides colonization is typical of saprophyte fungi. Externally, the fungus occurs on the fruit during all the phases of development. Initially, between October and March, with fruits from lead to sugarcanegreen, this colonization is less intense, not exceeding $25 \%$ of the fruits.

The difficulty to detect Cladosporium cladosporioides in the initial phases of fruit development can be related to the prevention of its manifestation due to the inhibition exerted by the fruit composts themselves (Goldstein \& Swain, 1963). The gradual fungus increase coincides with a conversion of phenolic composts in sugars, making the internal colonization of the fungus easier. These observations concur with Alves \& Castro (1998), who reported fungus colonizing cherry-stage as well as raisin-stage fruit. Internally, the fungus begins to manifest itself in March, when its maturation begins. From April onwards, the fungus is easily found in the external community of the grain. Thus in case of application of fungus inoculum as a bioprotective agent against fungi harmful to coffee quality, these should be done starting from the beginning of the maturation of the fruits.

If a mechanism of protection against undesirable fermentation is provided, the expressivity of quality coffee batches of the State and the producer regions would be amplified. This protection could be provided by the fungus applied over the surface of coffee fruits. As the microorganism grows, chemical alteration of the environment would allow protection from toxic composts (many of which have an antibiotic role), water sequestration or simple physical presence of the microorganism, hampering the development of other microbe populations. The main bioprotective activity of Cladosporium cladosporioides would reflect on the substrate, so the coffee grain would not be affected when the drying process is completed - the isolate vanishes, and does not presente any problem related to the safety of the final product. 


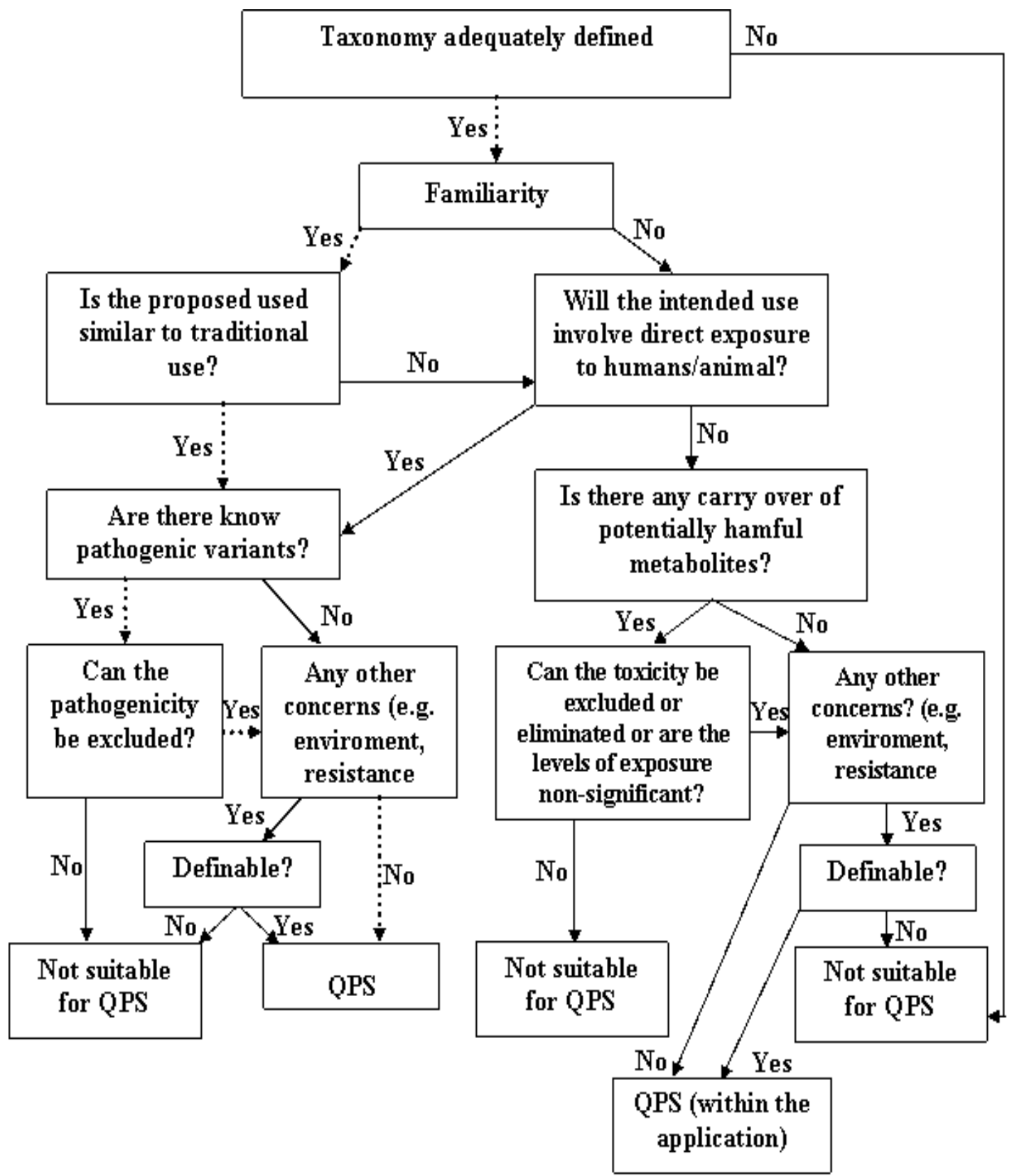

Figure 4 - General scheme for assessment of suitability for QPS (Qualified Presumption of Safety) status of microorganisms....$>$ Cladosporium cladosporioides (Fres.) de Vries, coffee bioprotection agent.

General considerations and the case of employment of Cladosporium cladosporioides (Fres.) de Vries as a biocontrol agent

Intensive use of agrochemicals has caused several problems, among them the progressive appearance of microbial varieties resistant to antimicrobials in all fields of microbiology, induced by abusive usage of those composts that put pressure for the appearance of resistance (Teuber, 1999; Andremont, 2001). This fact is aggravated by knowledge of possible carcinogenic teratogenic effects exerted by those products as well as residual toxicity (Eckert et al., 1994; Skandamis et al., 2001). There are also 
phases of the productive cycle (near or even after harvest) in which the application of chemical products is impracticable. To avoid occurrence of fermentation in coffee fruits still in plant, various measures have been tested or observed, such as the application of fungicide shortly before harvest, use of limestone or Ca solutions, or even disinfectant products based on quaternary amines. Although some results have been satisfactory, in certain cases, for example, four fungicide applications were necessary for the coffee to present a high quality standard (Chalfoun et al., 1992). These problems have reinforced the need to adopt more rational maintenance, and among the suggested practices we can highlight biological control (Robbs \& Bittencourt, 1998).

Nowadays biological control has assumed more and more importance in programs of integrated plague control in a moment when integrated production toward a sustainable agriculture is under discussion (Parra et al., 2002). For Vendramin (2002), the most adequate system for plague control is based on an integrated control using harmonious methods from different techniques according to ecologic, economic and social principles with the objective of keeping plague-organisms below the level of economic harm.

Post-harvest biological control of pathogens dates from 1953, when Gutter and Littauer demonstrated the antagonist action of Bacillus subtilis against pathogens of citrus fruits. However, it was only in the 1970's that research about the subject intensified, searching for microorganisms with biocontrol potential in conditions of storage and studies about their mode of action. Most works carried out about post-harvest biological control dealt with fruits, mainly those stored under low temperature. There are few works with grains kept in ambient temperature, such as coffee (Kretzchmar, 1991).

Coffee is harvested in the form of a fresh fruit and undergoes processing, mainly to lose water and undesirable structures. Its final product is a grain. To use a biocontrol agent, such as the fungus Cladosporium cladosporioides, the latter should be associated to the product as long as possible, that is, since the time the fruits were still on the plant, for it is in this phase that microorganisms harmful to the quality of the final product start acting.

There are two basic situations for the use of biocontrol: handling the natural, environment microflora, or introducing other microorganisms (Wilson \& Wisniewski, 1989). A good biological agent must be: a) genetically stable; b) effective in low concentrations; c) not tiresome; d) able to develop in diverse environment conditions; e) efficient against a wide series of pathogens and other aims; f) grow satisfactorily in cheap media; g) easily transported and stored; h) not produce secondary metabolites that can be harmful to humans; i) resistant to pesticides; j) compatible with other chemical and physical treatments of the product; k) not a pathogenic to the host.

Based on the criteria above, Cladosporium cladosporioides (Fres.) de Vries can be considered, after a preliminary analysis, as a potential antagonist agent against fungi harmful to coffee quality.

The selection and isolation of the antagonist constitute the most important phases when a biological control agent is sought (Wilson \& Chalutz, 1989). In the case of fruit biocontrol, the biological control agent can be sought both in the fruit itself and in the phyllosphere of the plant, which usually presents a similar environment. A wide isolation of potential microorganisms, simple in vitro testing, and deeper tests must be carried out in the microorganisms with better potential. The mechanisms of antagonist interaction between pathogenic microorganisms and antagonist fungi are similar to postharvest interactions and can be divided in antibiosis, competition, parasitism, predation, hypovirulence and host defense induction (Cook, 1985). Despite this division, an antagonist agent can act through one or more mechanisms; when this happens, there are more chances to succeed in control.

Among the mechanisms of action of Cladosporium cladosporioides, competition, referring to interaction between two or more organisms engaged in the same action, is the most probable one, due to its wide range of natural adaptation and also to its faster ability to colonize the substrate. However, antibiosis, which is the inhibition of microorganisms through the action of one or more metabolites produced by another organism, has also been demonstrated, testing extracts obtained from the fungus Cladosporium cladosporioides on sporulation and germination of spores of the fungi Fusarium sp., Penicillium sp., Aspergillus ochraceus and Aspergillus niger.

Antibiosis is based on the production of substances with fungicide, fungistatic, bactericide and nematicide functions. These substances are produced by antagonist organisms as a mechanism of protection of their survival in face of the other microorganisms in the microflora. Among organisms that produce antibiotics and are used in biological control of plant diseases, there is Bacillus subtilis, a bacteria that produces a wide array 
of antibiotics such as mycosubtilin, bacillomycine (Karel \& Roach, 1951), bacillin and fungicine (Loeffler et al., 1986; Tschen, 1987), and bulbiformin (Vasudeva et al., 1958), which are able to inhibit a wide array of pathogenic bacteria and fungi (Dunleavy, 1955).

Fungi of the genus Trichordema also produce various kinds of antibiotics (Valdebenito-Sanhueza, 1991; Baker, 1994). One of the most famous commercial uses is for the control of the gall of the crown of the rose; it is derived from bacteria of the genus Agrobacterium. In this case it produces an antibiotic substance called bacterin, which is capable of controlling the fungus (Kerr, 1980).

Parasitism or hyperparasitism consists of the degradation of cell walls or resistance structures of phitopathogenic fungi, with subsequent penetration in the fungus and absorption of the cellular content (Chet, 1987; Chet, 1990). Elad et al. (1982) demonstrated that enzymes cellulase and beta 1-3 glucanase are produced by Trichordema spp., when the fungus hyperparasites the cellular wall of Pythium sp. and that cellulase and beta 1-3 glucanase are produced when the fungus is put in the presence of Rhizoctonia solani e Sclerotium rolfsii. Ferreira (1989) reports that in the region of Viçosa, MG, Brazil, a species of Cladosporiumi hyperparasiting Prospodium bicolor (tabebuia rust) in its initial phase. In humid environments this fungus was widely found in rust sporulations. This mechanism also seems to be related to Cladosporium cladosporioides, regarding fungi associated with coffee fruits.

Competition is virtually the mechanism that coordinates the existence of all other biocontrol mechanisms, for what makes an organism to control another one is the very need for survival in a certain habitat, and it is often this competition that causes the equilibrium among the pathogen population. The phenomenon of biological control through competition involves mainly the dispute over nutrients and space. Speed of growth, as well as efficiency in absorption of certain forms of carbon, nitrogen and other mineral nutrients, determines the survival of microorganisms in some environments, as well as the succession of populations (Campbell, 1994; Paulitz, 1997).

Leite et al. (1995) also cite the existence of volatile composts produced by microorganisms as well as plants, which can act inhibiting and also stimulating germination and development of fungic pathogens. This is an important mechanism of control of soil fungi. Campos et al. (2010) present a complete review that shows the status of research and potential advancements in the area of volatiles produced by interacting microorganisms potentially useful for the control of plant pathogens, with undeniable benefits for farmers, especially in the aspects involving seeing suppressivity of the soil and tests with analogous molecules of the volatile organic composts highly toxic to plant pathogens.

Leong (1986) demonstrated the existence of a compost denominated siderophore, produced by Pseudomonas fluorescens and presenting a chelating effect by $\mathrm{Fe}^{+3}$. The siderophore makes iron unavailable to the other organisms that do not have chelating mechanisms.

Windels \& Lindow (1985) report CBD (coffee berry disease) caused by Colletotrichum kahawae, still inexistent in Brazil. In countries where the disease occurs, the application of fungicides, especially cupric ones, increased the incidence and severity of the disease. This fact was explained based on the observation that the biological control of the fungus was mainly due to competition for nutrients (especially sugars) with the natural microflora (yeast) of the leaves.

Consistent with these observations, Tokeshi (1991) argues that only by returning to a balance in terms of nutrition, as occurs in centers of origin or even forests, as well as restoration of a stable and competing micloflora, do we get satisfactory results in the biological control of diseases. Thus, the integrated management of all control factors are vital for maintaining and returning the biological balance.

Products of Biological Origin - development of an encapsulated formulation of the fungus Cladosporium cladosporioides (Fres.) de Vries

In a universe of 1400 registered pesticides in Brazil, only $16(1.14 \%)$ are organic. At the moment, however, there are at least 50 ongoing processes for the registration of new biological products, and if all 50 are approved, this participation will rise to $4.55 \%$. The Ministry of Agriculture, one of three agencies responsible for registering pesticides in Brazil - the others being the Brazilian Institute of Environment and Renewable Natural Resources (IBAMA) and the National Agency for Sanitary Surveillance (Anvisa) - launched a campaign to accelerate procedures in order to validate organic pesticides. According to Lopes (2009) the advantages of organic products, their safety in relation to pesticides, already well discussed in the literature, and the experience of its large scale use in several countries for many years are important for the revision of some aspects of the law. The possible relaxation or nuanced interpretation of the rules of registration, currently similar 
to pesticides, may reduce the need for heavy investments by companies and reduce dependence on foreign investment.

In Brazil, among the organic products available for use we can cite: CTV mild strains for pre-immunization against citrus tristeza disease, mild strains of PRSV-W for pre-immunization against zucchini mosaic; Hansford pulvinata to control the rubber tree leaf disease, Acremonium sp. for control of the coconut sandpaper; Clonostachys rosea to control gray mold, Bacillus subtilis for control of various diseases, Trichoderma spp. for control of soil-borne, substrate, and shoot pathogens (Morandi \& Bettiol, 2009).

Coffee regions located next to large water bodies (rivers, reservoirs) or under conditions of high relative humidity, even distant ones, are considered to be the most affected by microorganisms, with constant problems from loss of final product quality. It is estimated that $30 \%$ of the national coffee production (today consisting of 25 millions of hectares and 300.000 coffee growers), is in this condition. Added to this is the fact that in coffee plantations subjected to some types of management (Chalfoun et al., 2007), Cladosporium cladosporioides is drastically reduced or eradicated, not playing its natural role as bioprotector of coffee quality.

Under these conditions, there was the need to develop a formulation containing the fungus, so as to reintroduce it or balance its population in the coffee areas where, due to the aforementioned factors, the sensorial and safety characteristics of the coffee grains are harmed. Thus, the first tests consisted of developing formulations containing the biological agent, prolonging its viability under storage conditions and its establishment in the field.

Several studies show that the encapsulation of fungi, bacteria, yeasts and enzymes promote the formation of an excellent solid inoculant that is easy to apply, handle and transport. The immobilized microbial cells can be stored for long periods remaining viable to use. The encapsulation or immobilization has advantages over the traditional cultivation of microorganisms in culture media; for example, there are no costs with reagents, time, or space necessary for the maintenance of colonies (Fenice et al., 2000).

For the immobilization of cells different materials can be used as support. Alginate gels, carrageenan and polyacrylamide, alumina, Kanuma earth, sugarcane stems and silica are some examples found in literature holders, regarding the immobilization of viable cells (Corcoran, 1985; Pradella, 2001; Canilhas et al., 2006). This is a method that has been extensively studied for the immobilization of viable cells, due to the possibility of using biocompatible hydrophilic polymers such as media manipulation (Canilhas et al., 2006). Furthermore, the cells immobilized in hydrophilic matrix may be protected from inappropriate conditions of $\mathrm{pH}$, temperature, solvents or any compost that inhibits cell growth in this medium. Sodium alginate is a chemical compound - the sodium salt of alginic acid. Its empirical chemical formula is $\mathrm{NaC}_{6} \mathrm{H}_{7} \mathrm{O}_{6}$. It forms a gum when extracted from the cell walls of brown algae, and is used by the food industry and in the preparation of dental molds. Sodium alginate has no discernible flavor and its color ranges from white to yellow.

The method of entrapment in alginate gel is a technique extensively used for immobilization of microorganisms. As the gel formation occurs rapidly in the presence of calcium ions, without drastic changes in temperature, $\mathrm{pH}$ and osmotic pressure, the activity and viability of microorganisms immobilized are conserved (Corcoran, 2005; Elize, 2009). Advantages such as low cost, wide availability on the market, possibility of expansion in scale of production and acceptance of the substances used for immobilization (alginate and calcium chloride) as additives in food production have been cited in the literature (Corcoran, 2005), as well as the fact that alginate beads are naturally degraded after 120 days when used to inoculate microorganisms in the soil (Pethkar \& Paknikar, 2002). Institutions EPAMIG, UFLA and FAPEMIG, along with researchers Sara Maria Chalfoun (EPAMIG), José Carlos Pimenta (UFLA) and Marcelo Claudio Pereira (Researcher INCT-Café) are co-owners of patent PI 0406274-4, filed in 2004, with INPI (National Institute of Intellectual Property), which deals with the development of "Process Identification, Preservation and Use of the Fungus Cladosporium cladosporioides (Fres.) de Vries as bioprotector of Coffee Quality". It includes the process of immobilization of the fungus in a sodium alginate and calcium ions based matrix and it was proved that immobilization is a safe method where the fungus mycelium remains inside the granule, facilitating transport, storage and application(Figure 5).

The product is being improved and viability tests have been run during different periods of storage to reduce cost, without compromising conservation and establishment in the field, in order to preserve the quality of coffee fruits. It is estimated that it will be available for use by coffee farmers in a short time after the analysis performed to meet the technical and legal requirements of its registration. 


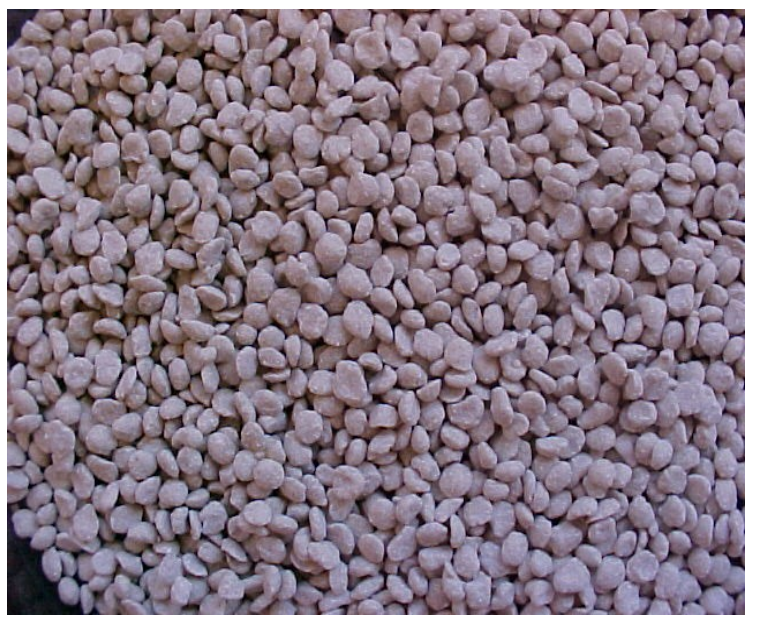

Figure 5 - Encapsulated fungus Cladosporium cladosporioides (Fres.) de Vries.

\section{Products and natural antimicrobials produced by fungi - prospects for the use of metabolites of Cladosporium cladosporioides (Fres.) de Vries}

For centuries, natural products have been exploited by man and the plants were the main source of composts used in medicine (Strobel \& Dayse, 2003). Because of their diversity and structural complexity, natural products are of great importance in pharmacology and biotechnology. They can also be used as a model of synthesis and semi-synthesis of bioactive broad spectrum, low toxicity molecules (Demain, 2006, Gullo et al., 2006). The best known example of natural products are antibiotics, especially the discovery of Penicillin by Alexander Fleming in 1928 and its production by Chain and Florey in 1940 (Demain, 2000).

Microorganisms, especially fungi, are known for their metabolic capacity to produce a wide variety of bioactive molecules. These substances in turn can be highly toxic, e.g., mycotoxins, or be quite useful because they can be used as drugs in various pathologies. This dichotomy of roles is a consequence of the wide variety of chemical compounds that fungi produce (Pinto et al., 2002).

In 1994, out of the twenty best-selling drugs, representing a market capitalization of approximately $\$ 6.7$ billion, six were obtained naturally or by chemical transformation of metabolites from fungi. Among the drugs of greatest therapeutic impact for infectious diseases the most outstanding are the antibiotics penicillin and cephalosporin as the most famous examples of products of fungi (Singh \& Barrett, 2006).

Bioprospecting for bioactive metabolites should be improved with the use of new technologies and alternatives such as genetic engineering and mutational biosynthesis, in addition to more rapid identification of molecules in an economically viable (Butler, 2004; Weist \& Sussmuth, 2005). Moreover, microorganisms are easy to manipulate in the laboratory. In recent years, new methodological approaches, especially molecular genetics, have been instrumental in generating a more complete picture of microbial ecology in a given habitat (Fungaro \& Vieira, 1998).

The search for new products to the pharmaceutical and agrochemical industries is a process that requires continuous optimization. Combinatorial chemistry and large-scale assays have revolutionized the process of drug discovery in pharmaceutical industries, where programs involving natural products have lost impetus. However, the expected impact of these new technologies on productivity has not been materialized (Newman et al., 2003). Natural products remain the most successful strategy for the discovery of new drugs (Harvey, 2000) as important tools for understanding the logic of biosynthetic pathways (Clardy \& Walsh, 2004).

Natural products have several advantages that justify its importance to the discovery of new drugs, including: a) large chemical diversity with structural complexity and biological potency (Verdine, 1996), b) various sources of natural products are still poorly explored, where new strategies for discovery could lead to new bioactive compounds (Henkel et al., 1999), c) research on natural products has led to the discovery of new mechanisms of drug action (Urizar et al., 2002), d) they are powerful biochemical tools serving as a guide for molecular biology and chemistry and the 
investigation of cellular functions, e) they can guide the design of new synthetic compounds (Breinbauer et al., 2002).

The diversity of functional groups and the architecture of molecules found in natural products during the processes of biosynthesis contribute to the synthesis and medicinal chemistry in strategies for the search of bioactive compounds and also to search for selective ligands of cellular targets (Clardy \& Walsh, 2004). Comparing the main supply sources of composts for new drugs (organic synthesis, natural products, combinatorial chemistry and virtual collections of compounds), the widest diversity is associated with chemical substances of natural origin (Harvey, 2000). With the continuing need for new prototypes for testing against a growing number of molecular targets, the chemical diversity of natural products remains highly relevant to the discovery of products since nature is continuously developing its version of combinatorial chemistry, providing structures rich in stereochemistry, concatenated rings and reactive functional groups (Verdine, 1996). However, the complexity of many natural products can limit the characteristics for chemical modifications that will optimize the development of new bioactive compounds (Clardy \& Walsh, 2004).

As an example of the fundamental role played by natural products in the process of searching for new prototypes, we can cite the statins, currently best-selling drugs, the anti-hypertensives antagonists of angiotensine and inhibitors of angiotensin converting enzyme, a wide variety of immunosuppressives and also the great variety of anticancer and antimicrobial agents available that are part of substances developed from natural products (Cragg \& Newman, 2005).

Researchers of natural products have turned their attention to sources still poorly investigated, such as marine microorganisms, extremophiles and endophytes (Cragg \& Newman, 2005). Associated with the processes of identification and cultivation of these microorganisms there are new techniques for isolation and identification as well as the manipulation of culture conditions for obtaining bioactive compounds.

\section{Production of metabolites of the fungus Cladosporium}

According to several reports, many fungi species are capable of causing antibiosis to other pathogenic organisms through the synthesis and excretion of toxic metabolites.

It is known that fungi antogonists like Cladosporium are described as hyperparasites of microorganisms like
Puccinia horiana, Uromyces.( gênero por extenso) appendiculatus, Cronartium flaccidum (Assante et al., 2004), and these have been used in biological control of plant pathogens. Although microscopic observations indicate that Cladosporium sp. acts as an antagonistic, one cannot rule out the possibility that the antagonism of this fungus may also be involved in other mechanisms such as production of antibiotics, toxic metabolites and enzyme production.

Several of the microorganisms used as biological control agents that produce secondary metabolites affect growth and germination through the production of antibiotics and / or enzymes that degrade the cell wall. Among the composts produced by fungi, cladosporol, a substance synthesized primarily by Cladosporium species, has been studied.

Assante et al. (2004) found that Cladosporium tenuissimum, producer of cladosporol $\left(\mathrm{C}_{20} \mathrm{H}_{16} \mathrm{O}_{6}\right)$, known as an inhibitor of glucan biosynthesis at concentrations of 12.5 and 100 ppm inhibited germination and mycelial growth of several fungi. Another work related to the metabolite synthesis was the isolation of cladosporol from the fermentation broth of Alternaria alternate. The effects of antitumor cladosporol in vitro and in vivo were investigated. The inhibitory effect of increasing cladosporol in vitro against six human cell lines of cancer was examined. The results showed that cladosporol selectively kills cancer cells and had a significant inhibitory effect on humans in vivo. Cladosporol also showed antitumor activity in mice that had gastric cancer. These results suggest that cladosporol also has potentially useful inhibitory effects on cell lines of gastric carcinoma. Sakagami et al. (2009) isolated Cladosporol (1) of the culture filtrate of Cladosporium cladosporioides. Cladosporol demonstrated an inhibitor of biosynthesis of $\beta-1,3$ glucans, and the structure of cladosporol was determined by spectroscopic analysis.

A series of pentacyclic composts, including the main metabolites with the production of cytokines and tyrosine kinase inhibitory properties, was recently isolated from Cladosporium cladosporioides (Wrigley et al., 2001). In a screening program dedicated to finding new and promising inhibitors such as topoisomerase I, the possibility of biotransformation of cladosporol derivatives of from the culture of Cladosporium cladosporioides was investigated (Sakagami et al., 1995).

Cladosporium tenuissimum isolates were selected and tested for their ability to inhibit in vitro germination of Cronatium flaccidum and Peridermium pini. The 
antagonistic exerted mechanical power to destroy the structures of spores by direct contact, penetrated the aeciospores and then proliferated within them. However, an enzymatic activity was also involved. This was shown by the dissolution of the host cell wall, and a minimum of swelling at the tip infecting hyphae. Culture filtrates of antagonists inhibited the germination of rust propagula. The cladosporol purified from the filtrate was characterized by chemical analysis and spectroscopy. The results indicated that in the different culture media - PDA (Potato Dextrose Agar), MPGA (Malt Extract, Peptone, GlucoseAgar) and glycerol + PDA (Potato Dextrose Agar + glycerol) with different extracts (hexane, acetate methanol and ethyl), cladosporol for each isolate was produced in different quantities, and in the culture medium MPGA the synthesis of the metabolite was higher.

Recent research conducted by Chalfoun et al. (2009) has demonstrated, through a bioassay, that the fungus Cladosporium cladosporioides (Fres.) de Vries, isolated from coffee fruits, is a source of various bioactive substances when different extractors are used, constituting an important tool in the search of new compounds for the control of Aspergillus ochraceus, A. niger, Fusarium sp., Penicillium sp. and Hemileia vastatrix. Although these studies relate to the performance of the fungus $C$. cladosporioides (Fres.) de Vries as a producer of toxic metabolites with inhibitory action on the sporulation and germination of fungal spores deteriorative to quality of coffee, producers of mycotoxins and pathogens, the results are applicable to other products, processes and foods, where these fungi are involved in causing damage. The results obtained allow to state that biological fungicides can be formulated through the combination of metabolites obtained from the different extractors used.

\section{Final considerations and future prospects}

Despite the low adoption rate of biological control measures and the unimpressive number of products of biological origin available in Brazil, the same cannot be said regarding knowledge of their basic concepts and principles and the advantages of their use. We are witnessing the awakening of the government sectors as sources of development projects, the need to use the stock of knowledge generated over the years by universities and research centers in the development of biological products for their application in several areas of human knowledge. Producers of agrochemicals and medicines see, in turn, that their survival is threatened due to shortening of the life of chemical molecules due to the constant occurrence of the phenomenon of resistance development of microorganisms to these molecules. Moreover, there is still a world claim for products free of chemical residues of any kind and harmless to the environment and workers. Demands such as these have motivated joint action of government agencies and the private sector, creating partnerships that benefit the various segments of society who depend on these inputs for the proper development of their activities.

Given this scenario, more and more incentives are expected for research projects about microorganisms potentially useful for different purposes, and after their identification and characterization, formulation and development of biological products at costs compatible with traditional treatments, preserving their qualities of conservation and efficiency of establishment in the habitat where they should exercise control over the target microorganisms.

This review reports also the pioneering experience of identification, characterization and granular formulation containing the fungus Cladosporium cladosporioides (Fres.) de Vries bioprotective with proven action on the quality of coffee. Once the product is launched, it will be the first biofungicide aimed at preserving the quality of coffee in the Brazilian market.

The secondary metabolites obtained from biological extracts, identified and characterized, may be directly utilized on a larger scale or guide the design of new synthetic compounds.

The diversity of natural products is still underused, considering that Brazil is one of the countries with greatest biodiversity in the world. It offers immense potential for the isolation of biological molecules useful and of great commercial value. In the future, this task, now performed mainly by research institutions, universities and small businesses (biofactories) will be taken up by large companies, as already observed in some initiatives cited in this review. It must be recognized, however, that the development of such products will always depend on a technological basis for the construction to which research institutions or company research departments should provide effective assistance.

\section{References}

ABDEL-BAKY, N.F.; ABDEL-SALAM, A.H. Natural incidence of Cladosporium spp. as a bio-control agent against whiteflies and aphids in Egypt. Journal of Applied Entomology, Hamburg, v.127, p.228-235, 2001. 
ABRUNHOSA, L.; SERRA, R.; VENÂNCIO, A. Biodegradation of ochratoxin A by fungi isolated from grapes. Journal of Agricultural and Food Enzimology, Washington, v.50, n.25, p.7493-7496, Dec. 2002.

ALVES, E.; CASTRO, H.A. de. Fungos associados ao café (Coffea arabica) nas fases pré e pós colheita em lavouras da região de Lavras. Summa Phytopathologica, Jaguariúna, v.24, n.1, p.4-7, jan./mar. 1998.

AMORIM, H.V.; MELLO, M. Significance of enzimes in non alcoholic coffee beverage. In: FOX, P.F. (Ed.). Food enzimology. Amsterdam: [s.n.], 1989. v.2, p.189-209.

ANDREMONT, A. The future control of bacterial resistance to antimicrobial agents. American Journal of Infection Control, Saint Louis, v.29, n.4, p.256-25, Aug. 2001.

ASSANTE, G.; SARACCHINI, M.; FARINA, G.; MORICCA, S.; RAGAZZI, A. Hystological studies on the mycoparasitism of Cladosporium tenuissinum and urediniospores of Uromyces appendiculatus.

Mycological Research, v.108, p.170-183, 2004.

BITANCOURT, A.A. As fermentações e podridões da cereja do café. Boletim da Superintendência dos Serviços do Café, São Paulo, v.32, n.359, p.7-14, jan. 1957.

BREINBAUER, R.; VETTER, I.R.; WALDMANN, H. From protein domains to drug candidates: natural products as guiding principles in the design and synthesis of compound libraries. Angewandte Chemie International Edition in English, v.41, p.2879-2890, 2002.

BUTLER, M.S. The role of natural product chemistry in drug discovery. Journal of Natural Products, v.67, n.12, p.2141-2153, 2004.

CAMPOS, V.P.; PINHO, R.S.C. de; FREIRE, E.S. Volatiles produced by interacting micorganisms potentially useful for the control of plant pathogens. Ciência e Agrotecnologia, Lavras, v.34, n.3, p.525-535, maio/jun. 2010.

CANILHA, L.; CARVALHO, W.; SILVA, J.B.A.

Biocatalizadores imobilizados: uso de células e enzimas imobilizadas em processos biotecnológicos.

Biotecnologia, Ciência e Desenvolvimento, Brasília, n.36, p.48-57, 2006.
CHALFOUN, S.M.; CARVALHO, V.D. de; GUIMARÃES, P.T.G. Manual de preservação e melhoria de café nas fases pré e pós-colheita. Guaxupé: EPAMIG COOPARAISO, 1992. 44p.

CHALFOUN, S.M.; CUNHA, R. L. da; CARVALHO, V.L. de; NOGUEIRA, D.A. Seletividade de fungicidas cúpricos e sistêmicos sobre o fungo Cladosporium cladosporioides em cafeeiro. Summa Phytopathologica, Botucatu, v.33, n.1, p.93-95, 2007.

CHALFOUN, S.M.; PARIZZI, F.C. Fungos toxigênicos e micotoxinas em café. In: BORÉM, F.M. (Ed.). Póscolheita do café. Lavras: UFLA, 2008. p.513-543.

CHALFOUN, S.M.; SOUZA, L.P.; PEREIRA, M.C.; PIMENTA, C.J.; BOTELHO, D.M.S. Antifungical potential of Cladosporium cladosporioides (Fres.)de Vries metabolites in reduction of coffee contamination by toxigenis Aspergillus genera. BioMicroWorld, Lisboa, n.259, Dec. 2009.

CHET, I. Mycoparasitism recognition, physiology and ecology. In: BAKER, R.; DUNN, P. New directions in biological control: alternatives for suppressing agricultural. New York: A.R. Liss, 1990. p.725-783.

CHET, I. Trichoderma: application, mode of action, and potential as biocontrol agent of soilborne plant pathogenic fungi. In:___. Innovative approaches to plant disease control. New York: J.Wiley, 1987. p.137-160.

CLARDY, J.; WALSH, C. Lessons from natural molecules. Nature, London, v.432, p.829-837, 2004.

CORCORAN, E. Lactose bioconversion by calciumalginate immobilization of Kluyveromyces lactis cell. Microbial Technology, New York, v.29, p.681-688, 2005.

CORCORAN, E. The production and use of immobilized living microbial cells. Topics in Enzyme and

Fermentation Biotecnology, v.10, p.815-819, 1985.

CRAGG, G.M.; NEWMAN, D.J. Biodiversity: a continuing source of novel drug leads. Pure and Applied Chemistry, v.77, n.1, p.7-24, 2005.

DEMAIN, A.L. From natural products discovery to commercialization: a success story. Journal of Industrial Microbiology and Biotechnology, v.33, n.7, p.486-495, 2006. 
DEMAIN, A.L. Microbial biotechnology. Trends in Biotechnology, v.18, n.1, p.26-31, 2000.

DUNLEAVY, J. Control of damping-off of sugar beet by Bacillus subtilis. Phytopathology, Saint Paul, v.45, p.252258, Mar. 1955.

ELAD, Y.; CHET, I.; HENIS, Y. Degradation of plant pathogenic fungi by Trichoderma harzianum. Canadian Journal of Microbiology, Ottawa, v.28, n.7, p.719-725, July 1982.

ELLIS, M.B. Dematiaceous hyphomycetes. Surrey: Commonwealth Mycological Institute, 1971. 507p.

FAVARIN, J.L.; VILLELA, A.L.G.; MORAES, M.H.D.; CHAMMA, H.M.C.P.; COSTA, J.D.; DOURADO-NETO, D. Qualidade da bebida de café de frutos cereja submetidos a diferentes manejos pós-colheita. Pesquisa Agropecuária Brasileira, Brasília, v.39, n.2, p.187-192, fev. 2004.

FENICE, M.; SELBMAN, L.; FEDERICI, F.; VASSILEV, N. Application of encapsuled Penicillium variable P16 in solubilization of rock phosphate. Bioresource

Technology, Essex, v.73, p.157-162, 2000.

FERREIRA, F.A. Patologia florestal: principais doenças no Brasil. Viçosa, MG: SIF, 1989. 570p.

FUNGARO, M.H.P.; VIEIRA, M.L.C. Aplicações da PCR em ecologia molecular. In: MELO, I.S.; AZEVEDO, J.L. de (Ed.). Ecologia microbiana. Jaguariúna: EmbrapaCNPMA, 1998. p.205-227.

GALLO, M.L.; SELDS, A.M.; CABRERA, G.M. Antibiotic long-chain and á,â-unsaturated aldehydes from culture of the marine fungus Cladosporium sp. Biochemical Systematics and Ecology, Palo Alto, v.32, p.545-551, 2004.

GOLDSTEIN, J.L.; SWAIN, T. Changes in taninis in ripening fruits Phytochemistry, Oxford, v.2, p.371-383, 1963.

GOMI, K.; HORIUCHI, T. Purification and characterization of a new enzyme, $\mathrm{N}$-alkylglycine oxidase from Cladosporium sp. G-10. Biochimica et Biophysica Acta, Amsterdam, v.1429, p.439-445, 1998.

GULLO, V.P.; MCALPINE, J.; LAM, K.S.; BAKER, D.; PETERSEN, F. Drug discovery from natural products.

\section{Journal of Industrial Microbiology \& Biotechnology,} v.33, n.7, p.523-531, 2006.

HARVEY, A. Strategies for discovering drugs from previously unexplored natural products. Drug Discovery Today, v.5, n.7, p.294-300, 2000.

HENKEL, T.; BRUNNE, R.M.; MULLER, H.; REICHEL, F. Statistical investigation into the structural of natural products and synthetic compounds. Angewandte Chemie International Edition in English, v.38, p.643-647, 1999.

KIRK, P.M.; CANNOM, P.F.; WINTER, D.W. Dictionary of the fungi. London: CABI, 2001. 665p.

KRUG, H.P. Cafés duros I. Revista do Instituto de café do Estado de São Paulo, Campinas, v.15, n.159, p. 636-638, maio 1940a.

KRUG, H.P. Cafés duros: um estudo sobre a qualidade do café de varrição II. Revista do Instituto de café do Estado de São Paulo, Campinas, v.15, n.163, p.1393-1396, set. $1940 \mathrm{~b}$.

KRUG, H.P. Cafés duros III. Revista do Instituto de café do Estado de São Paulo, Campinas, v.15, n.165, p.18271831, nov. 1940c.

LEONG, J. Siderohores: their biochemistry and possible hole in the biocontrol of plant pathogens. Annual Review of Phytopathology, Palo Alto, v.24, p.187-209, Sept. 1986.

LOPES, R.B. A indústria no controle biológico: produção e caracterização de microrganismos no Brasil. In: BETTIOL, W.; MORANDI, M.A.B. (Ed.).

Biocontrole de doenças de plantas: usos e perspectivas. Jaguariúna: Embrapa Meio Ambiente, 2009. p.15-28.

MODAK, J.M.; NATARAJAN, K.A. Biosorption of metals using nonliving biomass: a review. Miner. Met. Processing, p.189-196, 1995.

MORANDI, M.A.B.; BETTIOL, W. Controle biológico de doenças de plantas no Brasil. In: BETTIOL, W.; MORANDI, M.A.B. (Ed.). Biocontrole de doenças de plantas: usos e perspectivas. Jaguariúna: Embrapa Meio Ambiente, 2009. p.7-14. 
NEWMAN, D.J.; CRAGG, G.M.; SNADER, K.M. Natural products as sources of new drugs over the period 19812002. Natural Products Reports, London, v.66, n.7, p.1022-1037, July. 2003.

PARRA, J.R.P.; BOTELHO, P.S.M.; CORRÊAFERREIRA, B.S.; BENTO, J.M.S. Controle biológico: uma visão inter e multidisciplinar. In: PARRA, J.R.P.; BOTELHO, P.S.M.; CORRÊA-FERREIRA, B.S.; BENTO, J.M.S. Controle biológico no Brasil: parasitóides e predadores. São Paulo: Manole, 2002. p.125-142.

PAULITZ, T.C. Biologycal control of root rot pathogens in soilessand hydroponic systems. Hortscience, Alexandria, v.32, n.2, p.193-196, Mar. 1997.

PEREIRA, L.J.A. Influência de Cladosporium cladosporioides na qualidade da bebida do café. 2008. 236f. Tese (Doutorado em Engenharia Química e Biológica)-Universidade do Minho, Braga, 2008.

PETHKAR, A.V.; PAKNIKAR, K.M. Comparative studies on metal biosorption by two strains of Cladosporium cladosporioides. Biosource Technology, v.80, p.211-215, 2001.

PETHKAR, A.V.; PAKNIKAR, K.M. Recovery of gold from solutions using Cladosporium cladosporioides biomass beads. Journal of Biotechnology, v.63, p.121136, 1998.

PETHKAR, A.V.; PAKNIKAR, K.M. Thiosulfate biodegradation: silver biosorption process for treatment of photofilm processing wastewater. Process Biochemistry, London, v.38, p.855-860, 2002.

PETHKAR, A.V.; PAKNIKAR, K.M. Thiosulfate biodegradation: silver biosorption process for the treatment of photofilm processing wastewater. Process Biochemistry, London, v.38, p.855-860, 2003.

PINTO, A.C.; SILVA, D.H.S.; BOLZANI, V.S.; LOPES, N.P.; EPIFANIO, R.A. Produtos naturais: atualidades, desafios e perspectivas. Quimica Nova, São Paulo, v.25, n.1, p.45-61, 2002.

PITT, J.I.; BASÍLICO, J.C.; ABARCA, M.L.; LÓPEZ, C. Mycotoxins and toxigenic fungi. Medical Mycology, Oxford, v.38, n.1, p.41-46, 2000. Supplement.
PITT, J.I.; HOCKING, A.D. Fungi and food spoilage. 2.ed. Cambridge: Blakie Academic \& Professional, 1997. 593 p.

PRADELLA, J.G.C. Reatores com celulas imobilizadas: biotecnologia industrial. São Paulo: E.Blücher, 2001. $372 \mathrm{p}$.

ROBBS, C.F.; BITTENCOURT, A.M. Controle biológico de insetos: o controle biológico de insetos nocivos à agricultura com o emprego de fungos imperfeitos ou hifomicetos. Biotecnologia Ciência e Desenvolvimento, Brasília, n.6, p.10-12, jul./ago. 1998.

SAKAGAMI, Y.; SANO, A.; HARA, O.; MIKAWA, T.; MARUMO, S. Cladosporol, â.-1,3- glucan biosyntesis inhibitor, isolated by the fungus Cladosporium cladosporioides.Tetrahedron Letters, v.36, p.1469-1472, 1995.

SAMSON, R.A.; HOEKSTRA, E.S.; FRISVAD, J.C.; FILTENBORG, O. Introduction to food-and airborne fungi. 6.ed. Utrecht: Centraalbureau Voor Schimmelcultures, 2000. 389p.

SCHIMIDT, C.A.P.; MIGLIORANZA, E.; HOMECHIN, M. Microflora associada aos grãos de café em coco e beneficiado produzidos no Paraná.

Revista Brasileira de Tecnologia Industrial, v.4, n.1, p.10-18, 2010.

SILVA, C.F.; SCHWAN, R.F.; DIAS, E.S.; WHEALS, A. Microbial diversity during maturation and natural processing of coffee cherries of Coffea arabica in Brazil. International Journal of Food Microbiology, Amsterdam, v.60, n.2/3, p.251-260, Sept. 2000.

SINGH, S.B.; BARRETT, J.F. Empirical antibacterial drug discovery: foundation in natural products. Biochemical Pharmacology, v.71, n.7, p.1006-1015, 2006.

SKANDAMIS, P.; KOUTSOUMANIS, K.; FASSEAS, K.; NYCAS, G.J.E. Inhibition of oregano essential oil and EDTA on E. COLI 0157:H7.Italian Journal of Food Science, Pinerolo, v.13, n.1, p.55-65, 2001.

STROBEL, G.; DAISY, B. Bioprospecting for microbial endophytes and their natural products. Microbiology and Molecular Biology Reviews, v.67, n.4, p.491-502, 2003. 
TANIWAKI, M.H.; PITT, J.I.; TEIXEIRA, A.A.; IAMANAKA, B.T. The source of ochratoxin A in Brazilian coffee and its formation in relation to processing methods. International Journal of Food Microbiology, Amsterdam, v.82, n.2, p.173-179, Apr. 2003.

TOKESHI, H. Cana-de-açúcar. In: FERREIRA, M.E.; CRUZ, M.C.P. (Org.). Micronutrientes na agricultura. Piracicaba: Associação Brasileira para Pesquisa da Potassa e do Fosfato/CNPq, 1991. p.485-499.

URIZAR, N.; LIVERMAN, A.B.; DODDS, D.T.; SILVA, F.V.; ORDENTTLECH, P.; YAN, Y.; GONZALEZ, F.J.; HEYMAN, R.A.; MANGELSDORF, D.J.; MOORE, D.D. A natural product that lowers cholesterol as an antagonist ligant for F X R. Science, New York, v.296, p.1703-1706, 2002.

VALDEBENITO-SANHUEZA, R.M. Possibilidades do controle biológico de Phytophthora em macieira In: BETTIOL, W.; MORANDI, M.A.B. (Ed.). Biocontrole de doenças de plantas: usos e perspectivas. Jaguariúna: Embrapa Meio Ambiente, 1991. p.303-305.

VENDRAMIM, J.D. O controle biológico e a resistência de plantas. In: PARRA, J.R.P.; BOTELHO, P.S.M.; CORRÊA-FERREIRA, B.S.; BENTO, J.M.S. (Ed.).

Controle biológico no Brasil: parasitóides e predadores. São Paulo: Manole, 2002. p.511-519.
VERDINE, G.L. The combinatorial chemistry of nature. Nature, London, v.384, p.11-13, 1996. Supplement.

WEIST, S.; SÜSSMUTH, R.D. Mutational biosynthesis: a tool for the generation of structural diversity in the biosynthesis of antibiotics. Applied Microbiology and Biotechnology, v.68, n.2, p.140-150, 2005.

WILSON, C.L.; WISNIEWSKI, M.E. Biological control of pos-harvest diseases on fruits and vegetables: an emerging technology. Annual Review of Phytopathology, Palo Alto, v.27, n.2, p.425-441, Dec. 1989.

\section{WINDELS, C.E.; LINDOW, S.E. Biological control on the phyllopane. 2.ed. Saint Paul: American Phytopathological Society, 1985.}

WRIGLEY, S.K.; AINSWORTH, A.M.; KAU, D.A.; MARTIN, S.M.; BAHL, S.; HARDICK, D.J.; RAWLINS, P.; SADHEGHI, R.; MOORE, M. Novelreduced benzo[j]fluoranthen-3-ones from Cladosporium $c f$. cladosporioides with cytokine production and tyrosine kinase inhibitory properties. Journal of Antibiotics, v.54, p.479-488, 2001.

ZEIGLER, D.R.; PERKINS, J.B. The genus bacillus. In: GOLDMAN, E.; GREEN, L.H. (Ed.). Practical handbook of microbiology. 2.ed. New York: CRC, 2008. p.309-338. 